\title{
一般演題演説 要旨
}

\section{第 1 日 10 月 26 日（火曜日）}

\section{第 I 会場 午前の部}

$$
\text { ( } 1 \sim 21)
$$

1. 診断上興味があつた十二指晹狭宫の一治駼例 国立大蔵病院外科 ○井上宏司，呂俊彦 宇都宮利善, 大西英嚈，植村 用 小林 忠

われわれは最近，十二指腸閉塞をきたし，衍前検查成 績より，十二指晹原発の熏性腫煌と診断して手術を施行 したところ，術後の病理検査で，十二指腸の炎症性腫瘤 による閉塞と診断された 1 例を経験したので報告する． 症例：59才の主婦 主訴：悪心, 呕吐

既応歴 : 昭和27年頃, 肺結核 昭和 45 年 5 月, 軽度の脑出血 家族歴：特記すべきものなし.

現病歴： $4 \sim 5$ 年前より，時々，心窝部不快感があつ た．数カ月前より，悪心，呕吐が増強してきたので某医 を訪れたところ，幽門狭窄の診断で，当院を紹介されて 入院した.

胃 X-P で，十二指腸下行脚に閉塞をみとめ，十二指 腸覀性腫場の診断で開腹手術した，開腹所見は，十二指 腸周囲の諸脸器が病着のため一塊となっている.これら の恣着を娳離すると，十二指腸は，幽門輪直下の前壁飞 潰汮らしい所見がみとめられるが，狭窄はない，その約 $3 \mathrm{~cm}$ 肛門側に栗実大の腫瘤を触れ，膵頭部にも一部硬結 を触れる。十二指腸原発の悪性腫湯と診断して，膵頭十 二指腸切除を行なった。

切除標本の肉眼所見は，腫瘤の部分は全周にわたり瘦 痕性肥厚がみとめられ，粘膜面は乳嘴状を呈し，粘膜下 の瘁痕組織は硬く，その範围は約 $2.5 \mathrm{~cm}$ 亿及しでいる.

腫瘤の部の検鏡所見は，慢性炎症性の壁の肥厚がみと められるのみで悪性腫湯を思わせる所見はみとめられな W.

術後経過は順調で，54日後に退院し，現在何等支障な く正常生活を送っている.

2. Congenital extrinsic obstruction of the duodenojejunal junction（先天性外因性十二指腸空腸移
行部閉塞症）

佼成病院外科

○井上 勇, 松林冨士男 陳 守一, 三村正㴕，陳 慶忠 峰村協成，野田宏子，飯島勝一

先天性十二指腸閉塞症に関する報告は本邦に於ても数 多くみられるが，移行部に於ける外因性疮着性索状物に 体る狭窄に就いての報告は見当らない，われわれは最近 本症の 2 例を治験し得たので報告し垪せて文献的考察を 試みた。

症例1。生後第 7 日 男児

出生直後よりの胆汁性呕吐を主訴に S. 45. 10. 当小 児科に入院，生後12日目先天性十二指晹㹟窄の診断で開 腹す。

症例2．生後第33日 男児

生後 4 5 日目上り間歇性胆汁性呕叶あり次第泟症状 增悪を認め, 某院上り S. 45. 11, 当小坚科へ転院, 諸 検查の結果, 先天性十二指腸㹟窄の診断で生後36日目飞 手術施行.

症例 1，2 共に開腹するに，十二指腸は著明に拡張 し，Treitz 勒帯の所で空腸起始部は急敫に細まり，同部 に横走する巾約 $1 \mathrm{~cm}$ 宪着性索状物を認めた。.これを槑 離し同部に約 $1 \mathrm{~cm}$ 綖切開を加え下部腸管に生食を注入 し異常なきを確めまた逆行性に8号ネラトンを挿入 し，十二指腸に内因性狭窄のないことを確認，一次的に 閉腹した。衍後経過は共に良好で現在正常発育を遂げて いる.

わが国の文献にはこの種の狭窄に関する報告が見当ら ないが, 海外の文献に於ては古く1940に Haley が Treitz 鞄帯が狭く索状に附着すると同部を屈曲させて開塞を来 すと述ぺている．Louw は1960年にこの種の閉塞は回転

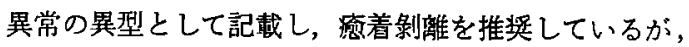
Lewis も十二指腸の不完全回㶿との立場をとっている. Nelson は1963年間歇的閉塞症状 も示す外因性閉塞症の 小児を十二指腸空腸移行部の単なる疮着剝離をもって治. 瘾せしめたと述べ Whiteは1963年, 外因性閉塞の23例を 挙げ,これらは回転異常に依るるのではなくして Trestz. 
勒帯の固定異常に帰因し，単なる癁着煣離で充分である と述べている．われわれも2症例をこの方法で完治せし めたので若干の考察を加党て報告する.

3. 腸間膜動脈性十二指腸閉塞の 3 例

大分赤十字病院外科 $\bigcirc$ 野松憲一, 清水 力 平塚弘之, 一瀬正昭

われわれは昭和39年以来，晹間膜動脈性十二指腸閉塞 の3 例を経験した。症例 1 は53才の男，上腹部痛と膨满 を主挀としその後悪心，屿听引゙現れイレウス症状が著明 で急性に経過した，症例 2 は37才の男，上腹部痛，膨满 感，覀心，呕吐を主訴とし慢性に経過した．症例 3 は21 才の男, 上腹部痛, 悪心を主訴とし症状・慢性に経過し た. 術前の透視所見では，症例 1 では苦痛が強く本検査 は施行出来なかったが，症例 2 では胃前庭部が左に圧迫 され，十二指腸球部が㧪張，上水平部に Niveau が認め られ，十二指腸は全体として拡張，造影剂は正中線より 左方に進行しなかった．症例 3 では十二指腸球部，更に 十二指腸全体が拡張し，造影阂は正中線より左に進行し にくかった．以上の所見から症例 1 では術前に本症の診 断をつけ得ず，急性イレウスと考光，また症例 2 , 症例 3 では本症と診断し得た。開腹するに 3 例共，腹水な く，胃は著明に払張し幽門は払大，十二指腸も全般に払 張し，十二指腸空腸曲部に於て，腸間膜根部により王迫 され，更に小腸は全般的に萎縮して一塊となり小骨盤腔 内に沈下し，本症に特有なる所見を呈していた。手術方 法としては 3 例共に，拡張せる十二指腸下水平部とトラ イッ勒帯より約10cm肛門側の空腸とを側々に吻合した. 術後の経過は全例共に良好で，愁訴は全く消失し，術後 の透視所見です通過状況の好転が認められた．本症の多 くは急性イレウスの症状で発病するといわれているが， われわれの場合症例 1 では同様な経過を示したが，他の 2 例ではやや慢性に経過し卯か興味ある症例と考えられ る. 本症の発現機序に就いてはいろいろ論議がある所の 様であり，またその術式も種々のるのが挙げられている が，われわれの経験からも十二指腸空腸側々吻合が良い 方法であると思われる。即か文献考察を加兄，われるれ の症例に就いて報告する。

\section{4. 腸回転異常の 4 例}

大分赤十字病院外科

○平塚弘之, 清水 力 野松憲一, 一瀬正昭

われわれの腹腔内消化管は胎生時期に 3 回の回転を行 ない正常の位置を占めるといわれている．この回転が途 中で中止したり，過度に回転したりまたは逆に回転した りすると腸回転異常が発生する。このうち第 3 期に起こ
る移動盲腸や，右上腹部に盲腸が存在するという盲腸の 早期固定などは，時折みられるようである。われれれ は，その発生が稀れといわれる第 2 期に起った回転異常 である Non-rotation の3例および Reversed-rotationの 1 例を経験したので報告する。

症例 1 は52才の女性である. 胃潰痬の診断で胃切除を 行なったが，十二指腸は腹腔の右側で下部小腸に移行し ており,トライッ氏勒带が認められなかった.小腸が腹腔 の右側に大腸が左側に偏して存在する，いわゆる Nonrotation であった。

症例 2 は47才の女性である. 結腸癌の診断で内科から 送られて来た患者である．脐左上部に腫瘤を認めた，開 腹し盲腸にある手挙大の腫瘤をふくめ回盲部切除を行な ったが，本症例す Non-rotation であった。

症例 3 は17才の女性である. 虫垂炎の診断で開腹した が，同じくNon-rotation で，盲腸は腹部中央よりやや左 方に存在していた。

症例 4 は59才の男性である. 胃癌の疑いで胃切除を行 なったが，横行結腸が背側にあり，その前方を十二指腸 が通っている，いかゆる Reversed-rotation であった.

以上，4例共，胎生時期における腸回転の第 2 期に起 った異常であり，殊に第 4 例は極めて稀れな症例である と思われる。

5. 乳幼児腸重積症の統計的観察 金沢聖霊綜合病院外科 ○相川公太郎，寉田裕之 中隆

過去10年間に当病院で手術した乳幼児腸重積症の統計 的観察を試みた。症例は 155例. 男女比に有意の差はな く，年令は 2 カ月から 5 才. 季節的に変動はない。

初発症状は急激な苦悶，啼泣，荅白，呕吐就よび浣腸 による血便である．当疾患の発生推定時から手術までの 時間は 3 時間から24時間。

手術所見 : 全例に浸出液を認め，18例は血性腹水多 量, 重積部位は回盲部で内䩗の長さは $2 \mathrm{~cm}$ よび, 浮腫, 出血斑, 肥厚を認め, 該部腸間膜の肥厚, 出血および血栓があり，淋巴節腫脤を来するのが多い。 4 カ月以下の乳児では腸管, 腸間膜, 淋巴節の病変は軽 度であり，単なる腸管虾動の失調が原因と思われるもの もあった，腸管の壊疽性変化を認めたもの3例.

手術方法 : 全例, 単純整復のみで腸切除または固定術 を行なったものはないり

予後は再発せるもの 5 例て，その中の 1 例は 3 回手術 施行. 死亡例は 1 例である。

以上，155例の乳幼児腸重積症手術経験より次の結果 
を得た。

低年令の者程，腸管，腸間膜の病変軽度であり，術式 は必要以上の侵襲は禁忌と思われる。なお，再発例を含 む該疾患の手術所見から病因に就いて考察し私見を述べ 度い。

6.重篤な経過をとつた乳幼児腸重積症（とくに仮性 整復に閵する考察について)

市立酒田病院外科

○大矢裕庸，金子芳弘 折居俊雄, 大島道一, 内田敬美

乳幼児晹重積による死亡率は最近は極く低いるのであ 万5.

治療は不手術的に整復されても，手術的に解除された あのでも重篤な合併症のないかぎり予後に不安はない。 私達が経験した乳幼児腸重積 145例（日本医科大学第 2 外科，昭 $32 \sim$ 昭 40 年, 82 例, 市立酒田病院. 昭 41 年 1 月～昭 46 年 5 月， 63 例）の5ち死亡は 5 例 ( $3.5 \%)$ で ある。

重篤な経過をとったと考えられるるのは死亡 5 例を含 む 9 症例で, 死亡例では来院直後に死亡した月令 1 カ月 例，生後 4 日飞発症し，72時間以上経過した症例が含ま れている。

治疮例ではイレゥス症状の著しい，発症後36時間以上 経過した 4 症例で, 重樍型はすべて Ileoileo Colic type, Ileoileo Colo-Colic type の多筒重積例であって, 経験 された多筒重皘例の50\%にあたる。

重篤な経過をとったこれら 9 症例について，このよう な経過をとるに至った要因を調查すると，診断が困難で あったと思われるすの 2 例, 受診がおくれたるの 2 例, 仮性整復によるるの 4 例, その他 1 例であって, 仮性整 復のため重篤な経過をとるにいたったるのが最も多い。 したがって乳幼児腸重積の治療に際しては重猜解除の診 断が治療成績向上の要点であると考える.

私達はこれまで重積解除前の腸管ガス像の動態から適 切な治療方法の選択が可能であることを報告してきた が，重積解除の診断がまぎらいい場合，解除後の腹部 単純撮影所見を検討することによっても容易に重積解除 の確診が得られることを知ったのでここれについての詳 細を報告したいと思ら。

7. 小腸重皘症13例の分析

東京都立墨東病院外科 ○出雲井士朗，山口真司 四方淳一

昭和28年〜昭和 45 年の18年間に当外科汸於いて腸重積 症 291例を経験しているが，このうち13例（小児 3 例， 成人 9 例) の小腸重積症について分析を試みた。
発生率は入院患者総数 17,769 例の $0.07 \%$, 全腸重積症 の $4.6 \%$ である. 内訳は空腸 3 , 空腸・回腸 2 , 回腸 8 の発生頻度でありその誘因として良性腫湟 2 , 腸七モ施 行後合併 2 , 直腸切断術後 1 , 娃娠合併 1 , メッケル㮩 室 1, 原因不明 2，であった。症状は腹痛が全例認め られたが，呕叶 9 ，血便 8 , 腫瘤触知 4 であった. 術前 診断はむつかしく，一部症例に注腸施行により回盲部重 積症を否定したにとどまり，報告の13例は全例開腹所見 による訩断である. 術式は腸切除 8 , 徒手整復 1 , 自然

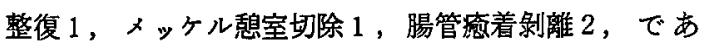
る。な抾䡆は直接死亡 1 , 間接死亡 1 であり，昭和 38

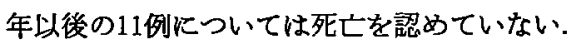

小腸重積症は内藤が1960年，340例の全国集計を行 なっているが，比較的稀な疾患である，その成因となる 基質的疾患が通常存在するにもかかからず，術前診断は むつかしい，反復自然整復をくりかえするのもとれ程稀 ではないと思われるが手術適応となる症例では腸切除を 要する症例が大半を占める以上診断上の進歩が 望まれ る.

\section{8. 外科でとり扱つた婦人科手術後々速症} 順天堂大一般外科 ○林田康男, 長浜 遠 村上忠重

同. 産婦人科竹内久弥

婦人科で手術を施行し, その後遣症の為外科を受診し 入院治療した例は，昭和42年 2 月より昭和 45 年 10 月まで の 3 年 8 力月間飞 37 例である. 同期間中の一般外科総入 院数は 2,976 例であるのでその $1.2 \%$ 占める．2,976 例中腸閉塞店状を主訴として入院した例は男珄28例女珄 46例，計74例であり，女性46例中婦人科手術々後遗症と しての腸閉塞例は実に23例 (50\%) を占めている.23例 の原疾患は子宮癌術後 8 例, 癌以外の手術の為の腸管瘾 着13例，偶発症 2 例である. 23例の腸閉塞以外の疾患と しては直腸ないし膀肶臆瘦 6 例, 腹壁瘦孔 3 例, 腹壁㴒 痕へルニフ 2 例, 下血 2 例, 不定の腹痛 1 例, 計14例で ある。

37例全例の原疾患は子宮癌16例, 子宮肉腫 1 例, 子宮 筋尰 3 例, 子宮外妊娠 2 例, 帝王切開 4 例, 卵巣 - 卵管 襄腫 9 例，その他 2 例である. 子宮癌16例中14例がコバ ルト60照射を受けており，この照射が外科的合併症の誘 発汇関保がある様に思われる。この意味に打いて放射線 療法の時期, 線量, 部位等に検討の余地がありそうであ る. 患者を年令別にみると30才代が10例，40才代 7 例， 50 才代 9 例，60才代10例，70才代 1 例で30才代の頻数は 卵栄・卵管英腫，50 60才代の頻数は子宮癌の好発年令 
に一致する．本学産婦人科の統計をみると卵巣・卵管衰 看の症例が増えている訳ではないので手術後の腹膜被覆 等手術手技に問題があるかる知れない，婦人科での外科 的治療法が進み広範囲手術が行なわれる程後迶症の為外 科え受診する患者む增えるものと思われるので，自験例 を統計的に検討した次第である．また外科の治療成績も 報告する。

9. 最近 5 年間のイレウス症例から得た知見

天理病院腹部 - 一般外科 ○前谷俊三，柏原貞夫 倉本信二, 羽白 洙, 金沢利定 相馬俊臣，佐藤 守，谷川允彦

最近 5 年間に経験した後天性腸閉塞 110 例を検討し て，その成因，治療法，予後に関して次のような知見を 得た。

原疾患として悪性腫湯による内腔閉塞中腸壁浸潤によ るイレゥスが增加した，消化器癌が明らかに将膜面まで 浸潤すると，たとえ拆大根治手術を行なっても，1年半 以内にイレウスとして再発し死亡する例が大多数であ る.またこれが癌末期の腹痛の主たる原因である.

屈曲イレウスの場合，局所の炎症や癌浸潤の外飞，これ より更に肛門側腸管飞軽度の通過障害部位を認めること が少くなくこれがイレウスの誘因と思われる例る多 い.この肛門側の通過障害部を放置すると、イレウスの 再発や梿合不全を招く恐れがある。

機質的閉塞や運動障害の外に，イレウスの原因として 腸管の分蜜と吸収のアンバランスが大きい役割を演しる と思われる例むある。

治療法として晹吻合を行なった場合，低フルブミン血 症中高尿素窒素血症㳊艇合不全の率が高い。前者はフル ブミンまたはプラズマネートの大量投与と経静脈栄盖が 著効さ示す場合がある．後者では術前の輸液で脱水や血 液濃縮を補正すると B U N る低下するが，50mg/d1以上で は䋖合不全の発生が極めて高い. 恐らく䋖合系による断 端の機械的結合が維持されている間㳊組織学的結合が完 成しないと想像される。

著者の一人は縫合不全を防ぐために，腸管の断端を内 䧽して vertical mattress suture により全層と粘膜層とを 同時に縫合し，かつ粘膜下層を厇く密着させて好成積を 得ている.

また Witzel腸瘦で腸壁を腹壁に固定する場合，腹壁 全層に Mattress suture を通し，皮唐側で系を結んで腸 内容の漏出を防ぐ方法を取っている。

10. 開腹術後の早期イレウスにおける $\mathbf{x}$ 線診断の検討 東京都立墨東病院外科 ○新井正美, 松尾泰伸
高橋正樹，落合治美，岩淵正之 石山秀由，四方淳一

昭和 40 年 1 月上り昭和 46 年 5 月までの開腹術症例のら ち 2 週間以内澄症し手術によって確め兄たイレウス症 例は12例であった．原疾患およびそ机に対する手術術式 としては穿孔性虫垂炎：虫垂切除術 2 例，胆豪結石症： 胆唯摘出術，横隔膜ヘルニア: 経腹的形成術, 潰瘍性大 腸炎 : 結腸切除術, 腸重積症 : 観血的整復術, 十二指腸 潰湯穿孔：胃切除術，胃溃瘍：胃切除術, 直晹癌：直腸 切断術, 胃癌: 胃全摘術, 食道癌: 食道胃吻合術, 右外 ソタイヘルニア嵌頓：観血的整復術，各 1 例であった。 大部分の症例では答着による小腸屈曲が原因となってい

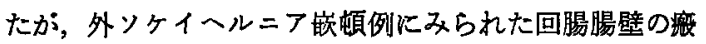

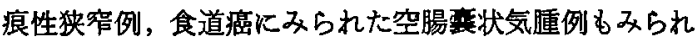
た。これらの屈曲部位や狭窄部位の口側と肛門側の腸巾 には判然たる差異があり，病着剥離ないし腸切除などに より軽快せることよりみて手術適応があった症例と思わ れる.これらの症例の症状としては排がスないし排便停 止, 汕痛性ないし持続性腹痛, 腹部膨满, 呕吐なぞであ った。 X線的には小腸巾は第 1 腰推横経以上に执張し， 立位像では我面像形成を認めた。，一方これらの症例と同 様の症状やX線所見から昖張小腸がス像を示したため1 レウスとして開腹せるる病着屈曲などとよる通過障害は 認められず腸巾は口側上り肛門側にかけて徐々に細くな っているのみの症例 6 例を経験した。これらの症例は手 術道応がなかったのではないかと考壳られる.これら両 群のX線像を比較すると小腸像に関しては略同様であっ たが結腸像を証明した症例は手術適応のあった群では12 例中 3 例過ぎなかったのに比し手術適応のなかった症 例では 6 例中 5 例を占めていた，これらのことより推睌: するに結腸像の有無はイレウス症状を呈した症例に战け る手術適応を決める際の一つの指標之考克られる。

11. ガストログラフィン経口投与によるイレゥスの診 断について

市立宇和島病院外科 ○香川嘉宏, 田中英夫 長島正明, 藤本隆敏, 藤原憲和 イレウスは臨床上, 小児回盲部重積症, 外ヘルニア嵌頓 症, $\mathrm{S}$ 字状結腸軸捻症, 単純性イレゥス, 以上のもの以外 の絞扼性イレウスに分けられるが，これらのらち前三者 については診断が比較的容易であり，手術適応とその時 期については容易に決断され得る。乙かし後二者につい て一特に過去数回の開腹術を受けている “polysurgery” の場合には一その診断と手術適応については必ずしも判 断が容易でないことは日常経験するところである。 
一般的なイレウスの診断基淮とその手術適応について は，四方等のイレウスインデックスの提唱，腸がス像と 推体との比較による判定等のニニークな研究があるが， これらの基準をむってしても個々の症例においては，必 す゚しす明快に手術適応を決定することは容易ではない．

演者等は過去 3 年間経験 したイレウス約50例のうち, 診断困難であったものに対し，手術適応の判定は，結局 は腸管閉塞の有無が決定的なポイントを占めているとの 観点から，ガストログラフィンの経口投与後, 経時的に 腹部レ線を撮影した結果腸管閉塞の有無を推定し，手術 適応の判定の有力な資料とすることが出来たのでその経 験を発表する。

成人では，ガストログラフィン $30 \mathrm{ml}$ を経口投与し， 服用後 $4 \sim 5$ 時間までの通過状態により閉塞の有無を判 定し，手術適応を決定出来ることが判明した。すすなわち 服用後 $4 \sim 5$ 時間後結腸像が得られない場合には腸管の 通過障害があり手術適応と判定した，逆に鏡面ガス像， 腸管螦動穴進等明らかに腸閉塞症状のある症例であって も，ガストログラフィンにより通過障害のない場合には 手術適応より除外した.

12. 局所性腸炎の臨床，とくに本症急性型の手術野に アニサキス仔虫を発見した 1 例

篮原病院（東京） ○古川 明, 乙部正治 過去18年間に，わたくしらは局所性腸炎約 120例を経 験したので, 年令・性・発病月・䛦断・治療・予後など につき，臨床的観察を行なった。

本症の原因，誘因については，いろいろな説があり， まだ一定していないが，近ごろて二サキス症が本症の急 生型と関係ありと認められる例が，しばしば報告されて いる.

最近わたくしらは，急性局所性回腸炎の1例におい て，手術野に生きたアニサキス仔虫を発見した。いまま での報告例では，主として切除例の組樴検査で，アニサ キス仔虫を発見している，板橋・佐々木によって，胃生 検鉗子で胃内の仔虫をとり出した例が報告されている が，手術野に生きた仔虫を発見した例はまだ見られない よらである。わたくしどの症例で発見した仔虫は，慈 大寄生虫学教室小林昭夫助教授の調查の結果, アニサキ ス仔虫 1 型と同定された。よってわずかに 1 例ではある が，症例を報告し，局所性腸炎とアニサキス症との関係 についての研究の一助としたいと思う.

13. アニサキス症に関する研究

一一とくに患者血清の免疫グロブリンについて— 札幌医大第 1 外科

○西野千鄉，浅石和昭
早仮 滉

腸アニサキス症は，その大半が回腸末端部に発症し， その腹部症状から急性虫垂炎と誤診され開腹によって， はじめて本症と診断されることが多く，免疫学的診断法 の開発が望まれている。

現在アニサキス症に関し多くの免疫学的研究がなされ ているが，臨床的にアニサキス症患者血清の免疫グロブ リンの解析に関する報告はいまだるんない，衆知のご とく血清蛋白の分析には多くの方法があるが，そのなか です免疫学的方法は, 精度, 分離能, 手枝などの点で他 の方法に比へ有利な点が多く，とくに一元平板免疫払散 法を用いた免疫グプリンの定量は，最近臨床的にもそ の有用性が認められるよらになった. われわれは，今回 本法によりアニサキス症患者血清について兔疫グロブリ ン, とくに $\gamma \mathrm{G}, \gamma \mathrm{A}, \gamma \mathrm{M}$ Kつき正常対照例, 扰よび 急性虫垂炎症例と此較検討し，腸てニサキス症において は血中 $\boldsymbol{A}$ Aが高値を示すといら結果を得た。

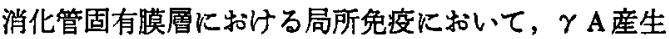
形質細胞が最近注目をあびており局所 Arthus 現象であ る本症と，血中 $\gamma \mathrm{A}$ の上型との関連について，いささか の検討を加克報告する。

14. 非閉塞性腸間膜動脈不全による広範囲消化管壊死 の1例

大阪医大第 1 外科 $\begin{gathered}\text { ○畐士原彰, 岡田 宏 } \\ \text { 秦 堅 }\end{gathered}$

大動脈弁および僧帽弁閉鎖不全を有する患者にみられ た非閉塞性腸間膜動脈不全に起因する広範囲消化管壊死 の症例について，その病理組織学的特長とともに，その 発生原因について検討を加え報告する。

症例は49才の主婦で，大動脈弁および僧帽弁閉鎖不全 のため内科で治療中，5 日前から心窩部痛，入院当日早 期から激しい痛みを訴え当外科に緊急入院して来た．手 術の結果，小腸空腸上部を残し，結腸にまでおよぶ広範 囲の罗死に陥っていた、剖検で主幹動脈に血栓はなく， 病理組織学的特長として, 細〜小動脈壁に弾性線維増殖 による著るしい中膜の肥厚が認められた。

15. 広範な腸管切除を行つた腸間膜血栓症の 2 例

国立東京第 2 病院外科 ○石山和夫，松本重喜 渡辺正幸, 丸田 潤, 正田達雄 木村 忠

腸管膜血栓症は腸管の壊死を伴ら為その予後不良とな る場合が少くない。

われわれは最近 2 例の腸間膜血栓症を経験し, 手術を 行なったので報告する。 
症例 1 .

23才。腹痛の訴えにより非観血的処咀を行なうも 改善せす愁訴持続の為，イレウスの診断の下に24時間後 開腹手術を行なった．開腹するに，腸管は約 $3 \mathrm{~m}$ にわた って変色壊死状熊に陥っていたのでその部分の切除を行 なった．術後 3 日にして再び下血を認めた為再開腹を行

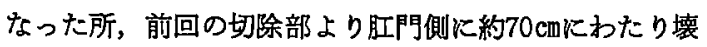
死状の腸管を認め，その部分の切除を行なった， 2 度の 手術で何れる腸間膜の血管に血栓を証明，それによる腸 管の壊死と考えられた。術後程過は良好で現在正常の社 会生活を行なっている.

\section{症例 2 .}

54才 。 . 腹痛を認めてより約 1 週間非観血的治療を 行なった後開腹した. 開腹時の所見は, 空腸下部より盲 腸に至る間の腸管の壊死が認められ，その部分の切除を 行なった，術後下血を認め，全身状態次第に低下し，術 後19日目に死亡した. 剖検により残存腸管に広範な壊死 および腹膜炎が認められた.

腸管膜血栓症は早期に発見し開腹手術により循環障害 による腸管の異常に対し切除術を含めた然るべき処置を 速に行なうべきであるが，早期に扣ける他の疾病との鑑 別診断は重要な問題点であろち.

16. 上腸間膜動脈塞栓症について

横浜市大第 1 外科 $\bigcirc$ 河野光紀, 城島標雄

天野富葶, 尾上正明, 有田峰夫 五島英迪, 和田達雄

最近，3 例の上腸間膜動脈塞栓症を経験した。

症例1.61才 家婦

兽帽弁閉鎖不全で内科治療中，粘血下片便と共に心窩 部激痛あり昏倒し救急訪医, ここで, 心電図上心房細動 を認め，腸間膜動脈閉塞症として紹介来院する.上腸間 膜動脈および右下肢動脈血栓摘除を行ならす, 状態悪化 し，更に広範囲腸切除および左下肢動脈血栓摘除を行な 5. 術後 5 日にて死亡, 剖検の結果, リニーマチス性心 内膜炎，上腸間膜動脈，腎，脾等の広汎な塞拴か;見られ た.

症例2. 64才 会社員

脳血栓症, 糖尿病の診断で 8 カ月来, 内科的治療中, 突然心䆟部激痛があり，同時に心房細動があった. 外科 転科，腸間膜動脈閉塞症の疑で開腹，広汎囲腸壊死と 脾, 肝の小壊死巢を認めた。広沉回腸切除, 空腸上行結 腸端々吻合，手術後，腹部所見の軽快をみたが，術後20 日で無尿となり死亡，剖検の結果，左心房に粘液腫があ った。極めて脆弱であり、これが塞栓となったるのと判
断された. 大脳，小脳，霄，脾にも硬塞を認め，動脈硬 化性の変化は，とこにもみられていない。

症例3. 53才 会社員

1 週間来右指のシビレ感あり，同時に刘周困の腹痛を 訴えていた，来院前日になり，激痛となり，心電図上心 房細動を認め，腸間膜動脈閉塞泟として内科より転科， 除細動後開腹, 上腸間膜動脈根部より広沉な塞栓があ ク，Fogarty カテーテルにて血栓摘除術をおこならも末 梢の壊死改善されず，広沉囲腸切除をおこなう．術後， 下痢が持続していたが，約半年後の現在 ${ }^{181}$ I 標識トリオ レイン消化吸収試験等を乩こなって指標としながら，栄 盖の改善につとめている.

以上，明らかに上腸間獏動脈塞栓症と思われる 3 症例 について若千の考察を加えて報告する．

17. 慢性晹間膜動脈閉塞症例について

久留米大第 2 外科 $\bigcirc$ 末永英文, 藤瀬嘉則 小須賀健一, 赤岩正夫, 中山和道 古賀道弘

本邦における腸間膜血管閉塞症例の報告は欧米に比べ て非常に少なく，特に慢性型と思われる症例の報告はき わぬて少い，われわれは最近本症例の 2 例を経験した。 症例 1 は38才の男子で腹痛持続し某医で急性虫垂炎の診 断で虫垂切除をうけるる症状の改善はみられず本科に転

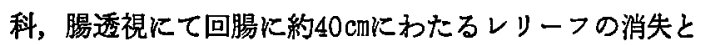
こん柈状の所見があり, 選択的上腸間膜撮影で上腸間膜 動脈根部の虫哈い像と回腸動脈の閉塞像を認め, 術前に 本症を確診し得た例で, 腸切除により治痣せしめえた。 症例 2 は50才の主婦で約 6 年前より食欲不振ひどく下浰 と便秘が交互に持続し，最近になり腹部膨満感が強く持 続するため本学内科に精密険査のために入院, 胸腹部レ 線単純写真で腹腔内特に両側横隔膜下に多量の空気像と 腸管内ガス像を認めた．入院中腹痛強度となり麻㿎性イ レウスの状態となり本科に転科救急手術を行なった，小 腸はトライッ勒帯肛門侧 $1.3 \mathrm{~m}$ より回腸末端より口側 1 $\mathrm{m}$ の部まで腸管壊死の状態にあり，また腸間膜根部は約 $90^{\circ}$ 時計の方向に回転していた, 同部の切除と二連銃式 腸淮造設を行なったが術後 7 日目に死亡した，剖検によ り胸部および腹部大動脈の動脈硬化, 石灰化あり特に上 下腸間膜動脈起始部に強い石灰化あり狭窄を来し上腸間 膜動脈末梢は殆んど閉塞に近い状態であった。

以上の 2 症例の詳細な内容と若干の文献的報告を加え て報告する。

18. 胃切後の小腸広筑囲切除 大阪医大第 1 外科 ○秦 堅, 臼井嘉幸 
森 志郎, 田辺治之

小腸広範围切除後飞, 下峲・体重減少・全身倦急等を 来すことは一般に知られている。

最近, 小腸広範囲切除に, 胃切除あるいは迷走神経切 断術を附加すると，これらの障害が減少するといわれて いる.

われわれは胃切11カ月後および 7 年後に急性小腸間膜 血管閉塞症で小腸広範囲切除術を施行した 2 例を経験 し たので報告し考察を加える.

症例1. 37才男

約11カ月前に胃潰場の為，B II 法で\%胃切を受けた. 12時間前から突然下腹部に鈍痛を来し,イレウスの診断 で開腹した，小腸は Braun 吻合部から回腸末端の約 5 Cm口側まで，壊死飞宿っていた，小腸間膜の血管には多 数の血栓かみられた。壊死に陷った小腸を切除し，端々 吻合を行なった。残存小腸は約 $70 \mathrm{cmである.}$

術後 5 日目から1 日 $1 \sim 4$ 行の水様便または軟便の排 泄があったが術後 3 週目頃から回数が減少し軟便となっ た. 1 カ月後に軽快退院した. 退院時には血清総蛋白 $5.2 \mathrm{gr} / \mathrm{dl} 1$ 日 1〜2行の軟便を呈するまで回復した。

症例2. 51 才男

約 7 年前に胃潰㡫の為B II 法で 14 胃切を受けた。

5 時間前加笑然腹部全体湟痛を来し, 急性腹症で 開腹した。少腸は胃腸吻合部から約 $1.5 \mathrm{~m}$ の部から回腸 末端まで罗死に陥っていた，小腸間膜血管に血栓を認め た。罣死に宿った小腸を切除し端々吻合を行なった。残

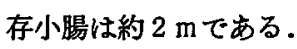

術後 5 日目頃から 1 日 $1 \sim 2$ 行の軟便の排泄があり, 10日頃から普通便となり体重の減少も殆んどなく 3 週目 に退院した。退院時の血清総蛋白は $6.4 \mathrm{gr} / \mathrm{dl}$, 貧血を認 めない.

Frederick 等（1964）は犬を用いて，小腸広範囲切除 を行ない，これに迷走神経切断衍，幽門形成術を附加す ると, 体重減少を防ぎ, 生存日数を延長させると述べ, Caridis 等 (1969) は，ラッテを用いて,小腸広範囲切除 を行ない，小腸内にある Histaminase 産生組織を大量に 切除すると, 胃酸分泌が著しく増加して, 吸収障害, 体 重減少を助長すると述へている.

われわれの症例は，小腸広範围切除11カ月前怙よび 7

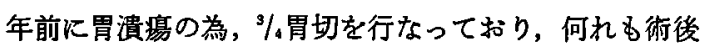
の体重減少, 血清電解質の低下む著明でなく, 経過良好 であった。

19. 肺意胞症を併発した新生児壊瘨性腸资の 1 手術治 醛例
日大第 1 外科 $\bigcirc$ 浜野晶平，小林 尚，東 说雄 岡部有夫

新生児期における原発性壊疸性腸炎が最近欧米におい て認識されてきたが，本邦における報告は未だ少ない， また新生児肺宾胞症の手術報告例るない，最近，われわ

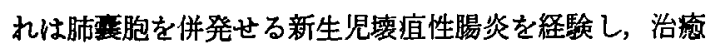
せしめ得たので報告する。

症例は生下時体重 $3,290 \mathrm{~g}$ の男児で, 生後 3 日頃より 呕叶，発熱特よび血便をみるようになり，生後 9 日より 腹部膨満, 胆汁性呕吐が出現し, 生後12日に入院した。

諸検查の結果, Entire colon aganglionosis の疑診にて

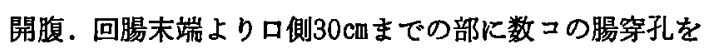
伴う限局性腹膜炎の所見を呈した. 迅速氷結切片により 回腸扰よび S 字結腸の筋間神経節細胞を証明し，回腸病

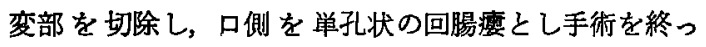
た. 切除回腸の組織所見は多発性潰湯, 粘膜下出血を伴 ら急性腸炎像であり，壊疸性腸炎之診断した。

術後は回腸㾯から出血はなかったが，7 日頃より $38^{\circ} \mathrm{C}$ 前後の発熱があり, 胸部レ線椧查にて右上中肺野に数 の肺烡胞を発見したが，自然治瘾傾向なく，むしろ悪化 の像を示したため，術後35日に右開胸により萑胞释縮術 を行なった，術後中葉の萁胞の拡大を認めたが，経過と とるに萣胞は縮小消失したので, 生後 3 カ月回腸瘦閉鎖 街を行なった経過良好である.

壊瘨性腸炎は, Sehwartzman 反応, Gram 陰性桿菌 の Erdotoxin による血管等縮, あるいは最近人工栄養児 にみられる Lysozyme の久乏が細菌感染を增強すること が原因とも云われている. 診断的には Hirschsprung 病 による急性小腸結腸炎との鑑別が最も重要となるが，い ずれにしてす末だ死亡率の高い疾患である。一方新生児 肺暴胞症す祭急手術を要する場合も多いが，その予後は 必ずしも良好ではない，新生児期に壊瘨性腸炎と肺菜胞 症を合併した症例を経験し，治瘳せしめえたので，これ ら 2 疾患について文献的考察を加えて報告する.

20. 中腸軸捻に対する二次的腸切除

.名市大第 1 外科

○䳡賀信䉆，由良二郎 高橋英城

腸回転異常における中腸軸捻は，時期を失すれば，上 腸問膜動脈支配額域全体におよふ広範腸切除を行なわね ばならない，かかる公範な腸切除は，現在の進歩した完 全非経腸栄羕をもってしても，術後管理は困難をきわめ る. しかも手術侵憝が非常に大きく, 新生児, 乳児に之 っては荷重な負担である。

この点につきわれわれは次の如き二期的手術を行ない 
良好な結果を得たので報告する。

すなわら第 1 回は輠捻を戻し，線維性に肥厚せる腸問 膜脚を䟝離拡大し，血流改善をはかり，胃瘦・十二指腸 瘦にて腸管内減王をしておくのみにとどめる．次いで第 2 回は, 第 1 回手術後24時間で再開㙏し, 改善された血 流のもとで,な颃に血行の悪い腸管のみを切除・吻合 するものである.

かかるフイデは，過去に全小腸に拈よぶ広範な血行 隆害のゆえに，軸捻解除のみで閉腹した症例の経験に立 脚している。この症例は良好な術後経過をとっていた が, 結局は壊死の進行していた極く小範囲の腸管の穿孔 により死亡したが，その穿孔に至るまでに実に19日を要 している.

軸捻解除後ある時間たてば，完全な壊死部以外は腸管 血流が物合に耐えらるよらに改善され，乙かる壇死部は 籁囲が相当に短縮される、その上，新妊児，乳児に長時 間の手術侵竟を一度に加える事なく，良好な条件で腸管 物合を行ないらる．同様なこころみは1969年の Z, Kinderchir K Hasse および Oelsnitz が別々に報告している が手術成功例は少い.

われわれの例では初回手術時には残しらる小腸は約 40 cmと考えられたが，2 回目には60cm（全小腸長 $110 \mathrm{~cm}$ ） を残す事が出来, intestinal huvry は認めていない.

21. 回腸末端部回晹間膜ヘルニアを伴つた Entire colon aganglionosis $の 1$ 例

賛育会病院小児外科 ○吉武克宏，今井武治 北原敏行，時松秀治，長島金二 同 病理

乾 道夫
患者は，生後 2 日の男児. 満期正常産で生下時体重 $3.8 \mathrm{~kg}$. 妊娠分婏等に異常なし. 生後12時間後より粶色 呕吐を覑回に認め，次第に腹部膨隆が現われる．腸閉塞 か疑われ，当科に送られてきた，入院時，柽度脱水があ

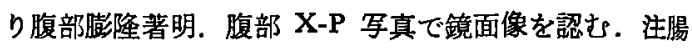
では大腸壁が，やや硬い感じを受けたが, microcolon で はなく，太さ走行共にほら゙正常. 下部小腸閉塞の疑いで 開腹術施行. 腸管を検するに回腸末端部約 $10 \mathrm{~cm}$ 晹間膜

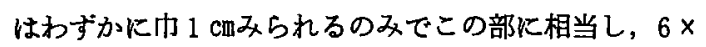
$6 \mathrm{~cm}$ の腸間膜の欠損があった，この欠損孔にロ側の小腸 が入り込み，この為へルニフ門に相当する回腸末端が压 迫され閉塞を起していた. 整復後, 血行障害のみられた 細い回腸末端部を $15 \mathrm{~cm}$ 切除し回腸上行結腸吻合を行ない 手術を終る，術後患児の状態は，はかばかしくなく第4 病日, 立位 X-P 写真で再び鏡面像を認めた. また切除標 本の病理学的所見として回腸招よび盲腸に神経細胞丵の 分布が見られないとの返答ありこのため, entire colon aganglionosis による腸閉塞と判断し，再開腹術施行し， 回腸度を造設したが，患児は術後 3 日目に死亡した。

本例は, 下部小腸閉塞の簃いで開腹し, 回腸末端部の 腸間膜欠損を伴った内へルニアが発見され，閉塞の原因 を単なる機树的閉塞と判断し整復後腸端々吻合を行な った所, 後に切除標本の病理学検索の結果 entire colon aganglionosis と判明した例である。

このよらに譏械的原因による腸閉塞と aganglionosis が合併している場合, 後者は見逃がされる可能性が大で あるのでこのよらな合併にも留意しなくてはならないと 考党る。

\section{第 I 会場 午後の部}

\section{特別講演 (13.00)}

手術と医事紛争（30分）

シンポジゥム 1 (13.30１5.00)

熱傷の治療 (90分)

\begin{tabular}{|c|c|}
\hline \multicolumn{2}{|c|}{ 司会者 } \\
\hline \multicolumn{2}{|c|}{ 演 者 } \\
\hline (1) & 熱傷の全身療法 \\
\hline (2) & 熱隹の局所療法 \\
\hline (3) & 熱傷潰瘍の治療 \\
\hline (4) & 熱傷後の痄痕ヶロイドの治病 \\
\hline
\end{tabular}

東京医大

穴田秀男
杏林大

東大分院
順天堂大・江東病院
関東労災病院
東京整察病院

林田健 男

$\begin{array}{llll}\text { 八 } & \text { 木 } & \text { 茂 } & \text { 久 } \\ \text { 村 } & \text { 烃 } & \text { 正 } & \text { 久 } \\ \text { 安 } & \text { 西 } & & \text { 喬 } \\ \text { 平 } & \text { 山 } & & \text { 峻 }\end{array}$ 
シンポジゥム $2(15.00 〜 16.30)$

癌手術之制癌㕮(90分)

司会者
演 者
(1) 胃腸癌の手術と化学療法
(2) 肺癌の手術と化学療法
(3) 肝癌の動脈内制癌剂注入療法
(4) 頭頸部癌の化学療法
(5) 癌化学療法の適疬と副作用

\section{第 II 会場 午前の部}

$$
\text { (22 42) }
$$

22. 創㗪痕内異所性化骨について 国立弘前病院外科

○遠藤尚孝，山形尚正 土田 博, 三上俊郎, 津島恵輔 笹村雅人，中村豊弥

異所性化骨の一つとしての進行性化骨性筇炎について は既に述べたが，(外科， $25 ， 758 ，$ 昭38）最近開腹創 痕内異所性化骨現象を相次いで 2 例経験したので報告す ると共に 2，3考察を加之た。

症例は 1 年前に屈曲性胆真て胆萣摘出, 6 力月前に十 二指腸潰湯で空置的切除術施行. 小腸の屈曲性イレウス にて再々開腹した際に発見したるのである。他の一例は

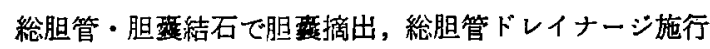
す. 術後胆道造影で総胆管遺残結石を認め, transpapillary choledocholithotomy した際に発見したものである.

腹壁術創撚痕内異所性化骨についての報告は，欧米で は比較的多いが，本邦では10数例を数えるにすぎない。 また異所性化骨の機転についてる，既存の骨膜あるい は骨組織より連続または颜散細胞の增殖を唱える特異細 胞説と，幼若結合轺の化成に上る骨発生を考兄る化成説 とに大別されているが，未だ定説はない．

また本症は外科臨床上，癌患者汇あっては，腹壁転移 と誤彭されたり，再開腹時に本症の存在を十分考㫘し， 処置飞当らねば腹腔諸䑏器損賃といら事もあり得る。

以上自験例を中心創軗痕内異所性化骨現象の発生機 転, 外科臨床上の諸点について述べた。

23. 巨大な良性副習皮筫腺腫の一治験例

慶大外科一般消化器外科

○山本修三,
日大
石 山 俊 次

$\begin{array}{llll}\text { 名古屋大 } & \text { 近 } & \text { 藤 } & \text { 達 } \\ \text { 東北大抗酸菌病研究所 } & \text { 鈴 } \text { 千賀忘 } \\ & \text { 橋 } \text { 本 邦 久 } \\ \text { 金沢大 } & \text { 木 南 義 男 } \\ \text { 慶 大 } & \text { 三 宅 浩 鄉 } \\ \text { 日 大 } & \text { 西 村 五 郎 }\end{array}$

永井 淳, 安藤幸史, 豊田精一 森川康英, 星野喜久

副腎皮質腺腫は一般に機能元進症状を伴うむのが多 く、いわゆる non-functioning adenoma は少いといわれ ている. 剖見例で約 $3 \%$ 認められるといわれる non-functioning adenoma は, いずれも数血程度のもので臨床的 意義は少い。大きな non-functioning tumor ではむしろ 癌が多く，時に $1 \mathrm{~kg}$ 以上の巨大な症例名報告されている が，巨大な腺隀の症例は，特に本邦に和いては未だ少 い. 最近われわれは，臨床的飞副腎皮質機能充進症状を 伴わない， $1 \mathrm{~kg}$ の巨大な良性副叕腺腫の一例を経験した ので，文献的考察を加兄て報告する.

症例は42才, 女性, 右季肋部痛および右季肋部腫瘤を 主訴として来院した。入院時所見および検査：右季肋部 に球形弾性硬，小児頭大の腫瘤を触知し，同部に压痛を 認めた. 肝シンチグラムで腫瘤部に一致して Space occupying legionを思わせる cold area を認めたが， $\alpha_{1}$ Fetoglobulin は陰性であった。 S C A の所見は肝動脈系 に明らかな腫煌性变化は認めなかった. 血棌17OH C S, 尿中 $17 \mathrm{OHCS}$ は軽度上昇を示したが，尿中17O S は正 常で, 満月顔, 皮䖉伸展条, 多毛, 高血圧等認めなかっ た. 手術所見：稙瘍は右後腹膜に位置し，被膜を有する 球形の尰晹で, 上面は右横隔膜, 下面は腎, 内側は下空 大静脈と強固に瘾着し肝右葉を後面より压排していた。 右開胸, 開腹にて畽笏を摘出した。腫瘍の大ささは10x

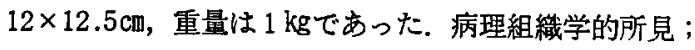
副腎皮質細胞に類似した細胞の增殖がみられ，分裂像は 顕著たが，異型性は軽度で被膜を越えた浸潤はなく，良 
性副腎皮質腺尰と診断された。術後著变なく5 週間で軽 快退院した。

\section{4. 腹部外科手術と娃㜊について} 市立半田病院外科

○武内義朗，石川修二 小出喜代之，小原嘉昌

女性の外科手術に際しては常に娃娠を考虑に入れてお。 く必要のあることは外科医の常識であろう，然し，妊娠 を知っている時には診断についてしばしば迷うるのであ り，知らない時には思わね経過をとり、ビックリさせら れることがある. われわれは過去 6 年間に Appendicitis Cystoma ovarii を始めとして, magenkrebs, Perforations-Peritonitis, lnvagination を妊娠 の前後に経験 したの でそれれらの症例について検討し，妊娠といら状態から 観た腹部外科手術の特殊性について考察を試みる。

25. 過去 5 年間における救急手術例の統計

武蔵野赤十字病院外科 ○徳水 剛, 高橋勝三 鈴木昌重，熱田不士行，松永康夫 里見 昭

昭和41年10月から46年 4 月までに报った手術症例数は 4,454 例で，救急手術例怯 1,374 例，約 $31 \%$, 月平均約 21 例である. 急性虫垂炎が最も多く 1,012 例，その内穿 孔あるいは腹膜炎を起していたるの119例，妊娠 6 例で ある。

季節による変動は認められない，消化管出血47例，そ の内穿孔32例である、イレウス78例で比較的多い疾患で ある. 外侮は28例であるが，脾破裂 3 例，膵破裂 1 例, 頭蓋内出血 3 例, 心タンポナーデ，肺損侮 1 例，耪腃破 裂 1 例, 大腿動脈切断 1 例，等で，外来手術例は除いて ある。その他の疾患としては，自然気胸，脍胸，腹腔内 出血，異物，腹膜炎，膿瘍等があげられる，小呪疾患 例としては, 腸重積症 61 例，嵌頓ヘル $=740$ 例が代表的 で，その他に横隔膜へルニフ，先天性胆道閉鎖，食道気 管支掼，鎖肚等があげられる．死亡例は26例で，急性虫 垂炎を除く症例数の約 $3.3 \%$ に当る.

以上，一地方総合病院外科注和ける手術例の実態を紹 介し，更に老人症例，合併症，死亡症例について検討す る.

26. 腹部外科疾患に対する動脈造影法の意義と有用性 について

関西医大外科 $\mathrm{O}$ 宾戸晃一, 增田芳夫, 松永征一 㚼 嘉也, 間島是武, 武田 惇 山本政勝

腹部外科領域に括ける血管造影法は，最近の10年間に 普及した Seldinger 氏法により，非常に容易に行ないら
るようになり，診断，治療の上で新たな一面を拓いたる のといえよう。

特に肝，粠などの実質脿器の疾患や腹部腫瘤の鑑別診 断には非常に有力であるのみならず，それら病変に対す る外科的手術適応可否の判定に重大な手掛りを与えてく れ，更には治療の目的で支配下動眽内汇高濃度の薬郕を 注入しらる利点がある。

今回，われわれの教室において，腹部疾患に対して動 脈造影を行なった症例 200例について検討し, 動脈造影 の意義および有用性と施行上の若干の注意事項について 述べる.

1. 血管走行の確認

肝動脈の走行異常は約 $22 \%$ に認められ，これを含めて 可成り多数に variation を認めた。このことは胃癌根治 手術等にあたって留意せねばならない重要な点である.

2. 胃癌梏治手術可能性の判定

われわれは立体的腹部動脈造影の所見から腹腔動脈幹 を $\mathrm{Y}$, 逆 $\mathrm{Y}, \mathrm{T}$, 逆 $\mathrm{T}$, Anomaly の 5 型飞分類 して観 察したが，Y 型， $\mathrm{T}$ 型は，根治手術不能例が殆んどであ った．また，䀒転移の有無は術前に可成りよく判断しら るようである。

3. 薬片の大量動脈内注入

われわれは以前化癌剤の術前投与の必要性を強調し たが，術前および術後にMMCの大量 One shot 腹腟動 眽内注入の有効性について報告する。

4. その他，睟肝脾および門六症の診断や，合併症防 止に対する検討について述べる.

27. 最近10年間に経験せる鼡径ヘルニア及び股ヘルニ アについて (第 1 報)

横㑟市立市民病院外科 ○山岸俊彦, 渡辺三作 石川徳久，北村錬三，杉山 貢 清家育郎，增沢千寻

ヘルニアに対する手術的㙩法は，唯一の確実な治療法 として，ひろく応用されている．しかるに近年，小児外 科の目覚しい進歩により小睍に和ける筩径へルニアは， その手術時期拉よび手術法てついては多くを論ぜられて いるが，一方，成人を含めた単径へルニアおよび股へル ニアについての全面的観察を行なった報告は少ない．

そこで私達は昭和 36 年当外科開設以来昭和 45 年までの 10年間に亘って入院手術を行なった単径へルニフおよび 股ヘルニフについて統計的観察を試みた。

上記期間中に外労径へルニフの根治手術を行なった. 患者は総計 993例であり，（両側性へルニアは2例とし て記載した).男 751例，女 242例，で男女比は $3: 1 て ゙$ 